\title{
Agata Jankowska
}

Uniwersytet Szczeciński, Wydział Humanistyczny

https://orcid.org/0000-0002-7884-7477

agatajnk@gmail.com

\section{Powojenne fotografie z obozów śmierci jako specyficzna odmiana ikonografii Zagłady i przykład fotografii forensycznej. Przypadek Bełżca i Treblinki ${ }^{1}$}

\begin{abstract}
Streszczenie
Artykuł podejmuje analizę archiwalnych fotografii z obozów śmierci w Bełżcu i Treblince, powstałych w ramach powojennych śledztw i oględzin. Autorkę interesuje szczególnie kondycja nie-ludzkich świadków: martwych ciał, rzeczy i elementów przestrzeni (krajobrazu). Jednocześnie, wykorzystując nowe teorie badawcze, takie jak zwrot wizualny (visual turn) czy zwrot forensyczny (forensic turn), stawia ona pytania o ich użyteczność w badaniach historycznych, wykraczającą poza tradycyjnie pojęte kategorie źródła i świadectwa. Kluczowe są tu pojęcia estetyki forensycznej, wrażliwości forensycznej i przeciwestetyki rozumiane nie tylko jako konstrukcje teoretyczne, lecz także jako praktyki czytania świadectw z miejsc zbrodni i miejsc po ludobójstwie. Wprowadzają one nowe perspektywy badawcze do ugruntowanych strategii dyskursywnych historiografii i studiów nad Holokaustem.
\end{abstract}

\section{Słowa kluczowe}

obozy śmierci, zwrot forensyczny, estetyka forensyczna, fotografia Holokaustu, dowód

\begin{abstract}
The paper discusses the archival photographs from the death camps of Belzec and Treblinka, taken during the postwar investigations. Using the new theories of visual turn and forensic turn, the author examines its usefulness in the historical research and goes out beyond the traditionally considered categories of the historical sources and testimony. The essential notions of forensic aesthetics, forensic sensitivity and counter aesthetics are considered here not only as the theoretical approaches, but also as the practices of the critical writing of the
\end{abstract}

\footnotetext{
${ }^{1}$ Niniejszy artykuł powstał dzięki funduszom przyznanym w związku z pobytem badawczym GEOP dla doktorantów i osób ze stopniem doktora, realizowanym w Muzeum Historii Żydów Polskich Polin i w Żydowskim Instytucie Historycznym im. Emanuela Ringelbluma w ramach Global Education Outreach Program, ufundowanym przez Taube Philanthropies, William K. Bowes, Jr. Foundation oraz Stowarzyszenie Żydowski Instytut Historyczny. Tekst jest również częścią mojej pracy doktorskiej pt. „Wizualna polityka pamięci. Fotograficzne strategie reprezentacji i dyskursów o nazistowskich obozach koncentracyjnych i Zagłady (1945-1999)", napisanej pod kierunkiem prof. Jörga Hackmanna w Instytucie Historii Uniwersytetu Szczecińskiego.
} 
testimonies from the mass killing cites. It sets the new research perspectives in the fundamental discourses of historiography and Holocaust studies.

\section{Key words}

death camps, forensic turn, forensic aethetics, Holocaust photography, evidence

\section{Wprowadzenie}

W swoich rozważaniach nad archiwalnymi fotografiami Zagłady proponuję interdyscyplinarne podejście skupione wokół tendencji teoretycznej określanej w nowej humanistyce jako zwrot forensyczny lub estetyka forensyczna. Opis i analiza zdjęć z obozów w Bełżcu i Treblince staje się tu pretekstem do dalszej refleksji zmierzającej ku sformułowaniu nowych klasyfikacji w studiach nad reprezentacją Holokaustu. Mają one postać kategorii dowodowej fotografii komisji śledczych jako źródła o odmiennym charakterze i perspektywie. W zdefiniowaniu tej specyficznej grupy materiałów ikonograficznych przydatne okazało się zaczerpnięte od Davida Shneera pojęcie fotografii forensycznej, które próbuję zdefiniować na postawie trzech tropów (dowodowego wymiaru obrazów, współczesnych użyć w ramach badań na terenach po obozach śmierci, estetyki forensycznej). Pytanie badawcze, jakie stawiam, brzmi: czy w badaniach nad historią obozów śmierci, ich powojennych losów, w tym przeprowadzonych śledztw, stosunku społeczności do tych miejsc, jak i historii nie-ludzkich innych zagłady, fotografie Bełżca i Treblinki mogą wnieść nowe spojrzenie na badane zagadnienia? Co więcej, czy do ich odczytania wystarczą tradycyjne metody krytyki źródła, czy też użyteczne mogą się okazać narzędzia tzw. zwrotu forensycznego i/lub estetyki forensycznej? Jednym słowem, czy potrzebujemy nowych rozwiązań teoretycznych dla przedstawionego wyżej materiału fotograficznego? Co do refleksji o Zagładzie może wnieść nie-ludzki świadek, którego obecność, biografia i naznaczona zniszczeniem tożsamość zostaje utrwalona w formie obrazu fotograficznego? Czy zainteresowanie sprawczością świadków jest przykładem paradygmatycznego przesunięcia, które skupia się na dowodach rzeczowych kosztem świadectwa ocalałych?

\section{Bełżec i Treblinka. Fotografie}

Zdjęcia wykonano podczas oględzin terenu obozu śmierci w Bełżcu w październiku 1945 r. Przeprowadzająca śledztwo Okręgowa Komisja Badania Zbrodni Niemieckich w Lublinie wynajęła do ich zrobienia fotografa, aby udokumentować materialne i postludzkie relikty masowego mordu na Żydach. Kilka fotografii przedstawia krajobraz obozu: piaszczysty teren zwieńczony szeregiem drzew. Jedno ze zdjęć pokazuje widok obozu od strony południowo-wschodniej, inne - tereny widziane od strony bocznicy kolejowej w kierunku wschodnim. Tylko pozornie sugerują pustkę - hałda piachu na pierwszym planie $\mathrm{w}$ dole fo- 
tografii to ziemia zmieszana z ludzkimi szczątkami, kośćmi, czasem zwęglonym drewnem ${ }^{2}$. Na zdjęciu, które przykuwa szczególną uwagę, widać rozsypane kości: z prawej strony patrzy na nas czaszka, przed nią leży dolny fragment szczęki, dalej pojedyncza kość. Jednak to, co rzuca się w oczy najbardziej, to fragment jakiegoś materiału z wyraźną gwiazdą Dawida ${ }^{3}$. Materiał przypomina ciemną rękawicę, a biała gwiazda wygląda, jakby ktoś celowo ją domalował. Nieznane jest przeznaczenie tego przedmiotu (być może miał on charakter rytualny?), jak również intencje tego, kto dorysował żydowski symbol (fotograf? archiwista?). Można jedynie domniemywać, że chciał w ten sposób wskazać na narodowość zabitych w obozie, wyróżnić Żydów jako ofiary zbrodni, co zasadniczo można byłoby uznać za gest przywrócenia pozytywnego znaczenia symbolu, który podczas okupacji służył jako narzędzie wykluczenia.

Fotografie zostały uzupełnione i uwierzytelnione oficjalnymi dokumentami ze śledztwa. W protokole oględzin obozu czytamy: „Na rozkopanym terenie leżą licznie rozrzucone kości ludzkie, czaszki, kręgi, żebra, piszczele, szczęki, protezy zębne kauczukowe, włosy przeważnie kobiece, często zaplecione w warkocze, nadto kawałki zgniłego ludzkiego ciała jak: dłonie, kończyny dolne małych dzieci. Poza tym na całym wyżej opisanym terenie leżą masy popiołu pochodzącego ze spalonych zwłok oraz resztki drutu kolczastego" 4 .

Odnalezione w dołach szczątki ludzkie stają się też obiektem analizy medyczno-sądowej. Zapis jej wyników został włączony do akt komisji i zawiera szczegółowe dane pochodzące ze wstępnej obserwacji lekarza sądowego pracującego na zlecenie prokuratury. Jest mowa o rozkopanych przez poszukiwaczy kosztowności dołach ze szczątkami: kościach, gnijących kawałkach tkanek, popiołach, włosach ludzkich. Wśród znalezionych kości znajdują się m.in.: czaszki, części czaszek, kręgi, żebra, obojczyki, łopatki, kości ramion. Ustalono, że pochodziły one od osób dorosłych w różnym wieku i płci oraz dzieci. Brakuje śladów po postrzałach czy uszkodzeniach mechanicznych, co sugeruje inną przyczynę śmierci. Ludzkie kończyny, jak można przeczytać, „uległy częściowo rozkładowi a częściowo mumifikacji”" Kończąca opis opinia lekarza sądowego poświadcza, że kości i popiół były ludzkie i pochodziły z dużej liczby zabitych. Stan zwłok potwierdza również wydobywający się z dołów nieprzyjemny zapach rozkładu tkanek miękkich, „wywołany skutkiem nasiąknięcia ziemi masowo rozkładającymi się ciałami ludzkimi, które po wydobyciu z ziemi zostały spalone" 6 . Zachowane materiały źródłowe mówią jednogłośnie o tym, co pozostało po obozie

\footnotetext{
${ }^{2}$ Żydowski Instytut Historyczny (dalej ŻIH), neg. Bełż 042, neg. GKBZPNP 67805.

${ }^{3}$ ŻIH, neg. 037.

${ }^{4}$ Protokół oględzin obozu śmierci w Bełżcu, Nr R. 102/46, Nr Ds. 1604/45. Zamość [w:] Obóz zagłady w Bełżcu w relacjach ocalonych i zeznaniach polskich świadków, red. Dariusz Libionka, Lublin: Państwowe Muzeum na Majdanku, 2013, s. 123.

${ }^{5}$ Protokół oględzin (z dnia 13 października 1945 r.), Nr R.102/46, Nr Ds. 1604/45. Zamość [w:] Obóz zagłady w Bełżcu..., s. 141

${ }^{6}$ Ibidem, s. $140-141$.
} 
w Bełżcu. Wspomina się o tym, co nad ziemią: o przestrzeni, krajobrazie zalesionym określoną roślinnością (sosnami), resztkach obozowej zabudowy, wreszcie o tym, co w ziemi, czyli ludzkich szczątkach i rzeczach po ofiarach ${ }^{7}$.

W oficjalnych zapisach ze śledztwa znajdują się również zeznania uczestniczącego w oględzinach fotografa. Był nim pochodzący z Tomaszowa Lubelskiego Antoni Tujak, który - jak zauważają także Dariusz Libionka i Robert Kuwałek w procesie zbierania dowodów uczestniczył też jako świadek. Jego zeznania włączono do akt sprawy. Dowiadujemy się z nich, że Tujak 10 października 1945 r. wykonał osiem fotografii Bełżca, a następnie przekazał je śledczym. Ilustrują one topografię terenu obozu, rozkopane przez kopaczy doły, budynki stacji kolejowej w Bełżcu, wał graniczny usypany w latach 1939-1940 i dół z ludzkimi popiołami, remizę kolejową, gdzie gromadzono rzeczy po ofiarach, wreszcie: szczątki ludzkie. Zespół dziewięciu innych zdjęć, które Tujak wykonał jeszcze w czasie funkcjonowania obozu, dokumentuje zbrodnie dokonane na Żydach w czasach, gdy obóz służył za miejsce ich eksterminacji ${ }^{8}$. W jego zeznaniu czytamy:

W dniu 10 października $1945 \mathrm{r}$. dokonałem zdjęć fotograficznych terenu byłego obozu śmierci w Bełżcu. Składam 8 zdjęć i wyjaśniam, że przedstawiają one co następuje: [...]. I. Widok terenu obozu śmierci od bocznicy kolejowej w kierunku wschodnim. II. Część środkowa obozu przylegająca do bocznicy kolejowej; III. Część południowo-wschodnia z wałem granicznym, usypanym w 1939-1940 r;; w głębi widać dół rozkopany z popiołem ludzkim, który oznaczyłem na zdjęciu krzyżykiem; VI. Teren północno-zachodni, przylegający do bocznicy kolejowej z widokiem wału granicznego, który stanowił północną granicę obozu śmierci; VII. Remiza kolejowa, w której składano odzież po zamordowanych żydach; VIII. Szczątki ludzkie, które znaleziono na terenie obozu; widoczne są włosy, protezy zębne oraz różne kości jak czaszki, kończyna dolna dziecka, itp. [... $]^{9}$

Fotografie z wizji lokalnej w Treblince podsuwają równie poruszające obrazy. Ich pochodzenie i autorstwo nie są do końca znane, a dostępne informacje podają, że zdjęcia zrobiono podczas wizyty pierwszej komisji badającej teren obozu

${ }^{7} \mathrm{~W}$ podsumowującym sprawozdaniu z wyników dochodzenia można przeczytać o czterech kawałkach modlitewnika w języku hebrajskim, dwóch opaskach z gwiazdą Dawida, metalowej gwieździe Dawida, tablicy w języku hebrajskim nakazującej zachowanie czystości podczas toalety oraz dolnej szczęce ze złotą koroną na jednym z zębów (Sprawozdanie z wyników dochodzenia w spr. obozu śmierci w Bełżcu, Nr R. 102/46, Nr 1. Dz. 1604/45 [w:] Obóz zagłady w Bełżcu..., s. 199).

${ }^{8}$ Protokół przesłuchania świadka z dnia 18 października 1945 r., Nr R. 102/46, Nr akt. Kps.302/45 [w:] Obóz zagłady w Bełżcu..., s. 186-187. Por. także: Materiały śledztwa z lat 1945-1946 w sprawie zbrodni popełnionych w obozie zagłady w Bełżcu [w:] ibidem, s. 110. Odbitki dziewięciu fotografii, które Tujak robił dla Niemców, przechowywane są obecnie w Muzeum Regionalnym w Tomaszowie Lubelskim. W artykule korzystam z odbitek dostępnych w zasobach Żydowskiego Instytutu Historycznego.

${ }^{9}$ Ibidem. 
zagłady, podczas gdy większość z nich datowana jest na 18 czerwca 1947 r. $^{10}$ Poobozowa ikonografia, podobnie jak w przypadku zbioru z Bełżca, zaczyna się od panoramicznego ujęcia krajobrazu i torów kolejowych ${ }^{11}$. Kolejne szerokie kadry odsłaniają puste i piaszczyste przestrzenie, czasem z fragmentami zabudowań trudnych do zidentyfikowania ${ }^{12}$. Na następnych zdjęciach, w rozkopanej ziemi, widoczne są porozrzucane kości i czaszki ${ }^{13}$. Kolejne zdjęcie to zbliżenie na „nogę w bucie"14 (jak głosi opis w notatce) - rzeczywiście zachowany fragment kości wystającej z rozpadającego się buta. Jest zdjęcie włosów z kawałkiem skóry ${ }^{15}$ oraz inne, z czaszką z „wyjętymi zębami” ${ }^{16}$. Fotografie charakteryzuje często powtarzający się widok czaszek właśnie z piszczelem i innymi kośćmi wokół, który wywołuje wrażenie pewnego toposu. Kilkakrotnie w zbiorze pojawia się fotografia - wykonana zawsze z innej perspektywy - niewielkiego dołu osuniętej ziemi wypełnionego porozrzucanymi kośćmi ludzkimi. Zmiany w krajobrazie: doły, leje, kopce piachu i niedopalonych szczątków kostnych to częsty motyw tych zdjęć. Naoczne sprawozdania z oględzin informują ponadto, że z ludzkimi szczątkami w ziemi Treblinki znaleźć można też rzeczy ${ }^{17}$. W prawym dolnym rogu jednej z fotografii rzeczywiście utrwalono stos naczyń, jeszcze na innej, zupełnie osobno, widnieją grabie (być może należące do poszukiwaczy kosztowności).

Obraz powojennego krajobrazu obozu śmierci w Treblince uzupełnia literacka relacja Racheli Auerbach, odsłaniająca skalę wyrządzonego okrucieństwa i zniszczenia w wymiarze ludzkim, ekologicznym i kulturowym:

${ }^{10}$ Odbitki fotografii dostępne w zbiorach Żydowskiego Instytutu Historycznego zostały przekazane przez Romę Byczuk. Podpis podaje jedynie, że zbiór pochodzi z oględzin pierwszej komisji badającej teren obozu, brakuje jednak konkretnej daty rocznej. Jedno ze zdjęć, na którym widać rozkopany dół, datowane jest w opisie na lata 1945-1947, w których rzeczywiście pracowały poszczególne komisje. Inne fotografie, zwłaszcza te ilustrujące szczegółowo znalezione w ziemi szczątki ludzkie, opatrzone są odręcznym dopiskiem z datą 18 VI 1947 r., wykonanym na załączonej do fotografii karcie przez pracownika ŻIH. Nieznane jest także nazwisko fotografa. Jak podaje Martyna Rusiniak, nie mogą to być fotografie z pierwszych oględzin dokonanych już w 1944 r. Identyfikacja osób uwiecznionych na zdjęciach, jak i stanu zachowania obozu każe identyfikować te fotografie na rok 1945 lub właśnie 1947. Odręczne datowanie dokumentacji na czerwiec 1947 r. byłoby zatem najbardziej prawdopodobnym wariantem. Por. Martyna Rusiniak, Obóz zagłady Treblinka II w pamięci społecznej (1943-1989), Warszawa: Wydawnictwo Noriton, 2008, s. 35-36.

${ }^{11}$ ŻIH, TRE 002.

12 ŻIH, TRE 007.

${ }^{13}$ ŻIH, 1772, TRE 019 (odbitki ofiarowane przez Romę Byczuk z Mińska Mazowieckiego do zbiorów ŻIH).

${ }^{14}$ ŻIH, 1755, TRE 017 (odbitki podarowane przez Romę Byczuk).

15 ŻIH, 1773, TRE 018.

16 ŻIH, TRE 023.

${ }^{17}$ Por. ŻIH, 209/38, „Extermination Camp at Treblinka”, Sprawozdanie z dotychczasowych wyników dochodzenia w sprawie obozu śmierci dla Żydów w Treblince. 
Na całym terenie nie ma ani jednego równego skrawka ziemi, wszystko wzruszone, rozgrzebane. Kopczyki i dołki. A na nich, w nich i między nimi - przede wszystkim - rzeczy. [...] Pozostałości ogromnych stosów żydowskiego mienia, które tu pakowano i wysyłano, palono i uprzątano, a jednak nie udało się tego całkowicie uprzątnąć. Nie udało się uwolnić od pozostałości po setkach tysięcy ludzi, którzy przeszli przez to miejsce. Dowody rzeczowe, corpora delicti. [...] Zapuszczamy się coraz głębiej w teren obozu i wchodzimy na pole usiane ludzkimi kośćmi. Bomby odsłoniły wnętrze zbezczeszczonej ziemi. Kości nóg, żebra, kawałki kręgosłupa, czaszki większe i mniejsze, krótkie i długie, okrągłe i owalne. Czaszki... ${ }^{18}$

Jest kilka punktów wspólnych, w których relacja Auerbach spotyka się z materiałem ikonograficznym: ogrom rzeczy po ofiarach, które świadczą o ich żydowskim pochodzeniu (choć fotografie pokazują raczej ich pojedynczość); szczątki ludzkie, które odsłania ziemia, wreszcie: przeświadczenie, że zbrodni nie można w pełni zatuszować, bo sprawcy zawsze pozostawiają po sobie ślady. Eseistyczna wrażliwość autorki reportażu zwraca się w stronę materialnych resztek, nie-ludzkich i postludzkich śladów ludobójstwa, które - jak zauważa Aleksandra Ubertowska - nie są jedynie tłem wydarzeń, ale ich pełnoprawnymi uczestnikami i aktantami ${ }^{19}$. Relacja żywych i martwych, tego co ludzkie i materialne staje się nierozerwalna i konstytutywna w myśleniu o Zagładzie, które $\mathrm{w}$ jakimś sensie antycypuje posthumanistyczną perspektywę zwróconą w stronę tego, co Ewa Domańska nazywa ekofaktami (w odniesieniu do rzeczy) i nekropersoną (czyli posiadającym sprawczość i wartość martwym ciałem) ${ }^{20}$. Potencjał nie-ludzkich aktorów-sprawców (natury, rzeczy, martwych szczątków) może mieć wymiar negatywny: sprzyjać intencjom sprawców (kamuflaż miejsc zbrodni), jak i pozytywny (natura odsłania ludzkie szczątki, demaskuje zbrodnie, udaremnia ją, konserwuje zwłoki itp.). Odczytując pisma Auerbach, literaturoznawczyni pisze:

Natura podejmuje grę w skrywanie/odsłanianie, w dialektykę wnętrza - zewnętrza, która w narracji Auerbach staje się „dyskursem prawdy”. Sprzeniewierza się intencjom sprawców i obnaża zawartość głębokich warstw gleby.

${ }^{18}$ Rachela Auerbach, Treblinka. Reportaż, tłum. Karolina Szymaniak, „Zagłada Żydów. Studia i Materiały" 2012, nr 8, s. 72-73. Relacja dziennikarki dotyczy wizji lokalnej przeprowadzonej 7 XI 1945 r. z udziałem członków Głównej Komisji Badania Zbrodni Niemieckich w Polsce i Centralnego Komitetu Żydów w Polsce. Miała ona charakter dochodzenia kryminalno-sadowego, z udziałem prokuratora i sędziego śledczego. Auerbach jako dziennikarka zrelacjonowała te wizytę $\mathrm{w}$ formie reportażu literackiego. Jej prace nad udokumentowaniem zbrodni w obozie śmierci w Treblince trwały jednak od roku 1942.

${ }^{19}$ Aleksandra Ubertowska, Rachela Auerbach opłakuje ślady, resztki, widma, wyrwy z ziemi, „Teksty Drugie” 2014, nr 1, s. 273-292.

${ }^{20}$ Ewa Domańska, Nekros. Wprowadzenie do ontologii martwego ciała, Warszawa: PWN, 2017, s. 57-59. Por. także tej autorki: Przestrzenie Zagłady w perspektywie ekologiczno-nekrotycznej, „Teksty Drugie” 2017, nr 2, s. 34-60; Ubertowska, Rachela Auerbach opłakuje... 
Wysiłek pedantycznego usuwania śladów zbrodni przez kremowanie zwłok wydobywanych z ziemi na specjalnych rusztach, nie powiódł się - ziemia w Treblince co krok odsłania obecność szczątków ludzkich zmieszanych z popiołem, ziemią i roślinnością ${ }^{21}$.

Podobną performatywność jak świadectwa Auerbach mają fotografie z obozów śmierci. Widmową obecność człowieka (ocalonego, świadka, śledczego, reportera, fotografa) przysłania niemal demonstracyjna sprawczość rzeczy, natury i szczątków, a właściwie ich ulegających rozkładowi resztek, wprowadzając jednocześnie zakłócenia w tradycyjnie rozumianym (narracyjnym, pisanym, antropocentrycznym) dyskursie świadka i świadectwa. Stanowią one jednocześnie wyzwanie dla usankcjonowanych metod uprawiania historii wywodzących się z krytyki źródła (przede wszystkim pisanego) i tworzonego przez ludzi i o ludziach.

\section{Fotografie (po)wojennych komisji śledczych jako specyficzna odmiana fotografii Zagłady}

Systematyczne gromadzenie dokumentacji i dowodów rzeczowych przez powołane do tego specjalne organy, czyli komisje śledcze złożone z biegłych sądowych, wojskowych, fotoreporterów, świadczących konkretnie o regularnym i zaplanowanym ludobójstwie Żydów i zbrodniach przeciwko innym narodom, było specyfiką okresu powojennego ${ }^{22}$. Pierwsze wizje lokalne przeprowadziła powołana przez rząd ZSRR w 1942 r. Sowiecka Nadzwyczajna Komisja ${ }^{23}$. Praktyka wykonywania reportażu z miejsc po „Holokauście od kul” (Patrick Desbois) wydaje się w każdym przypadku podobna: od zdjęć szerokiego kadru, przez zbliżenia na detale i szczegóły w postaci materialnych dowodów zbrodni, często oglądanych przez śledczych, wojskowych lub miejscową ludnośćc ${ }^{24}$.

Działania sowieckich ekspertów przeniosły się do Polski po wyzwoleniu obozu na Majdanku w lipcu 1944 r. Dowody ludobójstwa, jakie znaleziono na jego

${ }^{21}$ Ubertowska, Rachela Auerbach opłakuje..., s. 290-291.

${ }^{22} \mathrm{O}$ powojennych dochodzeniach na terenach poobozowych pisze Caroline Sturdy Colls, Holocaust Archaeologies. Approaches and Future Directions, London: Oxford University Press, 2015, s. 25-26.

${ }^{23}$ David Shneer, Is Seeing Believing? Photographs, Eyewitness Testimony, and Evidence of the Holocaust [w:] The Holocaust. Memories and History, red. Victoria Khiterer, Ryan Barrick, David Misal, Newcastle upon Tyne: Cambridge Scholar Publishing, 2014, s. 64-85. Pierwszym odkrytym i zbadanym miejscem masowej zbrodni były groby 7 tysięcy ofiar w miejscowości Kercz. Kolejnym był Babi Jar ze szczątkami ponad 100 tysięcy ludzi. Do dzisiaj miejsce to uważane jest za jedno z symboli Holokaustu. Fotografie z ekshumacji pokazują ogromne doły z ludzkimi szczątkami, krajobraz spustoszony destruktywnym działaniem człowieka, kopce z popiołów i piachu.

${ }^{24}$ Przykładem takiego fotoreportażu są zdjęcia z wizji lokalnej w obozie Kołdyczewo. Na serii fotografii zobaczyć można ludzi stojących nad dołami wypełnionymi ludzkimi szczątkami oraz starsze kobiety opłakujące zmarłych (ŻIH, BAR. 0044, BAR. 005). 
terenie: krematoria, ludzkie szczątki w stanie rozkładu, kości, ogromne ilości mienia ofiar (butów, dokumentów, przedmiotów religijnych) wyznaczyły nowy etap w procesie dokumentowania zbrodni. Bogaty materiał ikonograficzny poświadczał wyniki ekspertyz prowadzonych przez Polsko-Sowiecką Komisję Nadzwyczajną ${ }^{25}$. Majdanek był nowością, jeśli chodzi o sposoby zabijania i pozbywania się ciał, przez co natychmiast zyskał nazwę „fabryki śmierci”26. Systematyczny wymiar zbrodni ilustrują fotografie skupione na dowodach rzeczowych. Udostępniane światu przez radzieckie agencje materiały prasowe w pełni oddawały monstrualny wymiar zbrodni, jak jednak podaje Barbie Zelizer, była to zbrodnia bardziej industrialna i mechaniczna. Policyjno-śledcze ujęcie tematu ludobójstwa potrzebowało, jak pokazały historie wyzwolonego kolejno Auschwitz i obozów koncentracyjnych w Niemczech, na których skupiła się cała uwaga świata, innego sposobu patrzenia i rejestrowania ludzkiego cierpienia. Amerykańskie i brytyjskie ujęcia oparte były na kreatywnej inscenizacji i kompozycji obrazu. Była to, mimo swych walorów dokumentalnych i technicznych, silnie estetyzująca konwencja wykraczająca poza proste, rejestrujące kadry, skierowana do masowego odbiorcy na Zachodzie ${ }^{27}$.

Specyfika tych fotografii wskazuje na nową jakość w porządku reprezentacji Holokaustu. Wprowadzają one inną perspektywę przede wszystkim w zestawieniu z bogatym zasobem zdjęć wykonanych przez Niemców, określanych w literaturze jako „zdjęcia trofea”. To obrazy, które naziści wykonywali po wkroczeniu na tereny Polski i Związku Radzieckiego, będące zapisem akcji eksterminacyjnych wymierzonych w ludność żydowską. Wiele z nich zyskało status ikonicznych fotografii Zagłady, jak na przykład zdjęcia egzekucji kobiet w Mizoczu, Lipawie czy Międzyrzeczu Podlaskim, fotografia z rozstrzelania kobiety z dzieckiem w Iwangrodzie, fotografie nagich mężczyzn zrobione na krótko przed egzekucją (prawdopodobnie w Śniatynie) - by wymienić jedynie niektóre ${ }^{28}$. Do fotografii-trofeów, realizujących nazistowskie spojrzenie, wprowadzających dehumanizującą kategoryzację fotografowanych ludzi-obiektów i jednocześnie realizujących postulaty rasistowskiej i narodowosocjalistycznej ideologii zaliczają się również zdjęcia z gett, w tym najsłynniejsze z likwidacji getta warszawskiego w kwietniu 1943 r., wykonane do tzw. Raportu Jürgena Stroopa, jak również zdjęcia z obozów koncentracyjnych. Część z nich powstawała w celach

${ }^{25}$ Komisja publikowała wyniki śledztwa w postaci szczegółowych komunikatów. Por. Prawda o Majdanku, Lublin: PKWN, 1944; Komunikat Polsko-Radzieckiej Komisji Nadzwyczajnej do zbadania zbrodni niemieckich dokonanych w obozie unicestwienia na Majdanku w Lublinie, Moskwa: Wyd. Literatury w Językach Obcych, 1944.

${ }^{26}$ Shneer, Is Seeing Believing?..., s. 71.

${ }^{27}$ Barbie Zelizer, Remembering to Forget. Holocaust Memory Through the Camera's Eye, Chicago-London: University of Chicago Press, 1998, s. 57. Por. także: Janina Struk, Holokaust w fotografiach. Interpretacje dowodów, tłum. Maciej Antosiewicz, Warszawa: Prószyński i S-ka, 2007.

${ }^{28}$ Struk, Holokaust $w$ fotografiach..., s. 103-107. Por. Nadine Fresco, Śmierć Żydów. Fotografie, tłum. Magdalena Kamińska-Maurugeon, Wołowiec: Czarne, 2011. 
dokumentacyjnych, urzędowych, pozostałe mimo oficjalnego zakazu zostały wykonane indywidualnie ${ }^{29}$. Jak pisze Janina Struk, ofiary były tu przedstawiane według znanego wzorca: żydowskich mężczyzn pokazywano w „kategoriach [...] religii i kultury", kobiety z kolei upokarzano ze względu na ich płeć. Wszystkie te obrazy łączy to, że zostały wykonane na krótko przed śmiercią, w jej trakcie lub po egzekucji ${ }^{30}$. Są one nie tylko świadectwem bestialstwa i określonych intencji sprawców. Fotografie te, ze względu na „estetykę dehumanizacji” i specyfikę nazistowskiego spojrzenia, budzą dziś etyczne wątpliwości oraz epistemologiczne spory na temat zasadności ich upubliczniania ${ }^{31}$.

W tym kontekście fotografie komisji śledczych realizują inne sposoby patrzenia i ustanawiania obrazu. Wynikają one z intencji - są źródłami wywołanymi na potrzeby toczących się śledztw: ustalenia okoliczności zbrodni, sposobów zabijania, eksploatacji zwłok, ogólnej tożsamości ofiar (wiek, płeć, narodowość), co tym samym miało wpływ na sposób rejestracji fotografii zgodny z kryteriami procedury śledczej. Jednocześnie, jako że wiążą się one z określonymi działaniami prawno-politycznymi, są również ogniwem nowego porządku i nowej, komunistycznej władzy. W refleksji nad reprezentacjami Zagłady ważne jest, że inicjują inną perspektywę w kontekście statusu świadka i strategii dawania świadectwa: w obozach śmierci prawie nikt nie pozostał przy życiu, przez co $\mathrm{w}$ imieniu zmarłych przemawiają dowody rzeczowe i ludzkie szczątki. Uzasadnione byłoby zatem twierdzenie, że powojenne materiały komisji śledczych wprowadzają nie-ludzkiego (rzeczowego, materialnego, postludzkiego) świadka do dyskursu na długo przed zwrotem ku materialności i perspektywą posthumanistyczną.

\section{Fotografia forensyczna. Próba charakterystyki}

David Shneer, badając pierwsze próby wizualizacji Zagłady przez sowieckich fotografów, słusznie używa terminu „fotografia forensyczna” (forensic photography) ${ }^{32}$. Aparat ma rejestrować określone punkty z miejsca zbrodni: dowody i miejsca. Stąd właśnie obrazy przestrzeni, które dopiero przy bliższym ujęciu odsłaniają detale, odkrywane w miarę jak fotograf wkracza i eksploruje terytorium. Fotografie te można traktować jako inną formę świadectwa, pierwotną ikonografię, która prawdopodobnie w większości nigdy nie miała wyjść poza ar-

${ }^{29}$ Struk, Holokaust $w$ fotografiach...

${ }^{30}$ Ibidem, s. 105. O fotografiach kobiet Holokaustu por. także: Janina Struk, Images of Women in Holocaust Photography, „Feminist Review” 2008, nr 88, s. 111-121.

${ }^{31}$ Przykładem dyskusji toczącej się wokół fotografii Zagłady jest spór między francuskim historykiem sztuki Georges'em Didi-Hubermanem i Claude'em Lanzmannem. Por. Georges Didi-Huberman, Obrazy mimo wszystko, tłum. Mai Kubiak Ho-Chi, Kraków: Universitas, 2008.

${ }^{32}$ David Shneer, Ghostly Landscapes. Soviet Liberators Photograph the Holocaust, „Humanity: An International Journal of Human Rights, Humanitarianism and Development" 2014 , t. 5, s. 235-246. 
chiwa i którą z czasem zastąpiły wizerunki ludzkich świadków - wyniszczonych okrutnymi warunkami i głodem więźniów ${ }^{33}$. Proponuję, aby fotografie z obozów śmierci stanowiące zasób dokumentacji powojennych komisji śledczych uznać za przykłady fotografii forensycznej. Samo pojęcie nie jest nowe i wiąże się z powszechną praktyką fotografowania miejsc zbrodni. Na korzyść zastosowania tej kategorii do omawianego materiału wizualnego przemawiają przynajmniej trzy argumenty (tropy) odnoszące się do performatywnego potencjału tych zdjęć w przeszłości, jak i obecnie, od praktyk powojennego zbierania dowodów rzeczowych i dokumentacji, aż do współczesnych użyć na potrzeby badań archeologicznych przeprowadzanych na terenach miejsc pamięci. Ostatnim przykładem byłaby strategia estetyki forensycznej rozumianej jako forma wypracowywania nowych, emancypacyjnych sposobów odczytania obrazu fotograficznego.

\section{Trop pierwszy: fotografia jako materiał dowodowy}

Związek fotografii z forensyką wynika z pierwotnych sposobów użycia jako część materiału dowodowego i/lub materiału dokumentującego zastaną na miejscu zbrodni sytuację, dowody czy ślady ${ }^{34}$. Razem z pozostałymi ustaleniami w postaci protokołów, sprawozdań, komunikatów czy zeznań świadków stanowią wyczerpującą dokumentację, dostarczającą wiedzy o sposobach przeprowadzania pierwszych śledztw po wojnie, ich wynikach czy ówczesnych metodach dochodzeniowych.

Dowodowy charakter fotografii i sytuacje, w jakich powstawały, narzuca sposób ich odczytania. To materiały towarzyszące dokumentacji kryminalistycznej, której celem było zebranie dowodów niemieckich zbrodni przez specjalnie powołane organy śledcze. Konwencja tych obrazów nie jest przypadkowa: najpierw pokazany zostaje krajobraz przez zastosowanie szerokiego kadru, z widokiem połaci i roślinnością w tle. Następnie fotograf zwraca się ku szczegółom:

${ }^{33}$ Odmiennym przykładem są fotografie z obozu Auschwitz wykonywane na zlecenie komisji. Niektóre z nich, np. słynne zdjęcie torów i wieży strażniczej w Birkenau, zrobione przez Stanisława Muchę w 1945 r., stało się ikoniczną reprezentacją Holokaustu.

${ }^{34}$ Forensykę pojmuję tutaj w znaczeniu, jakie proponuje Zuzanna Dziuban, jako wiele procedur kryminalnych i sądowych, opartych na wypracowanych przez kryminalistykę, medycynę sądową i prawo metodach badania miejsc zbrodni. Współcześnie metody te używane są w odkrywaniu miejsc po ludobójstwach, również miejsc Holokaustu. Zadaniem forensyki jest przede wszystkim identyfikacja szczątków ludzkich i zabezpieczenie innych dowodów rzeczowych. Dziś, dzięki wysoko zaawansowanej technologii, rezultaty śledztw są nieporównywalne $\mathrm{z}$ tymi, jakie zdołano uzyskać podczas pierwszych powojennych oględzin. W humanistyce mówi się o „zwrocie forensycznym”, który wyznacza nowe pola badawcze dla antropologii, historii, kulturoznawstwa itp. Zob. Mapping the Forensic Turn. Engagements with Materialities of Mass Death in Holocaust Studies and Beyond, red. Zuzanna Dziuban, Wien: New Academic Press, 2017, s. 12-19; Human Remains and Identification. Mass Violence, Genocide and „Forensic Turn”, red. Élisabeth Anstett, Jean-Marc Dreyfus, Manchester: Manchester University Press, 2017. 
dowodom rzeczowym. Materialność zbrodni wpisuje te fotografie w dyskurs prawno-kryminalny, ale jednocześnie wskazuje na płynność praktyk i porządków, w jakich mogą zostać usytuowane (od dokumentu, przez materiał dowodowy do archiwum). Pierwszą z nich jest dokumentacja $\mathrm{w}$ formie wizualnego utrwalenia tego, co widoczne. Fotograf staje przed trudnym zadaniem dowiedzenia, że w danym miejscu i czasie doszło do zbrodni na ogromną skalę, że miejsce, gdzie tego dokonano, nie jest miejscem rytualnego pochówku, ale specjalnie wyznaczonym do zbrodniczych celów terenem. 0 ile rozrzucone wśród piachu i roślinności ludzkie szczątki mogą potwierdzać, że miejsce, na którym leżą, nie jest cmentarzem, a ich ilość może wskazywać na masowe mordy, o tyle niełatwo udowodnić na ich podstawie coś ponadto, a więc także samo istnienie obozu jako dobrze zaplanowanej i systematycznie działającej fabryki śmierci. Na tym etapie obraz potrzebuje potwierdzenia, uwierzytelnienia: zapewniają je inni świadkowie i pozostałe świadectwa (zeznania, protokoły, ekspertyzy) ${ }^{35}$, co jednocześnie podaje w wątpliwość jego autonomiczność i przypomina o jego niepewnych związkach z rzeczywistością. Podejmując próbę czytania wizualności należy brać pod uwagę jej indeksalność, jak chciałby tego teoretyk fotografii André Rouillé: „Odcisk dominuje nad mimesis. Albo raczej mimesis opisuje, podczas gdy odcisk poświadcza" 36 .

Ta wątpliwość każe zadać pytanie, co te fotografie właściwie pokazują, lub przeciwnie, czego nie chcą (bądź nie mogą) pokazać? Pewne jest, że utrwalają stan obozu po likwidacji, zaorany i zalesiony w celu ukrycia śladów zbrodni, a następnie wyeksploatowany przez miejscową ludność. Z pewnością, o czym przecież donoszą także protokoły, poświadczają rodzaj śmierci - gwałtownej, nienaturalnej i zadanej w jeszcze nie do końca jasny sposób. Przekazują ponadto kolejną fundamentalną informację o tym, jak postępowano ze szczątkami ludzkimi: że poza kremacją (czego dowodem są spopielone resztki kości) ciała grzebano także w masowych mogiłach. Co więcej, zachowany po wojnie stan odkrywa również prawdę o tym, iż utylizacja zwłok przebiegała w sposób chaotyczny, źle zaplanowany i źle zarządzany. Te fotografie dowodzą, że mimo usilnych starań w pozbyciu się śladów masowej zbrodni, w ostateczności okazało się to nieskuteczne. W ten sposób negują przekonanie o sprawnie działającym niemieckim planie systematycznego zabijania. Stanowią dowód nie tylko genocydu, lecz także pośmiertnych praktyk odmowy prawa do pochówku i bezczeszczenia ciała ofiar, nekrobójstwa ${ }^{37}$.

\footnotetext{
${ }^{35}$ Roma Sendyka, Stać na miejscu śmierci [w:] Rzeczowy świadek, red. Katarzyna Grzybowska, Sylwia Papier, Roma Sendyka, Kraków: Wydawnictwo UJ, 2019, s. 93-94.

${ }^{36}$ André Rouillé, Fotografia. Między dokumentem a sztukq współczesną, tłum. Oskar Hedemann, Kraków: Uniwersitas, 2007, s. 103.

${ }^{37}$ Domańska, Nekros..., s. 191.
} 


\section{Trop drugi: współczesne użycia w ramach praktyk archeologii sq̨dowej}

Obrazy fotograficzne stanowią kluczową technikę wizualizacji dowodów zbrodni, co wynika poniekąd z długiej tradycji związku fotografii i nowoczesnej kryminalistyki. Uwaga ta dotyczy zarówno zdjęć wywołanych, powstałych na potrzeby śledztwa i badań (np. na miejscu zbrodni lub w laboratorium), jak i zdjęć pochodzących z innych źródeł. Ważne, aby w kontekście relacji fotografii i zwrotu forensycznego wyraźnie zaznaczyć funkcję fotografii dokumentalnej w przeciwieństwie do obrazów współczesnych. Caroline Sturdy Colls, prowadząca prace na terenie obozu w Treblince, widzi w dokumentalnych fotografiach Holokaustu spory potencjał poznawczy ${ }^{38}$.

Omówione archiwalne fotografie można uznać za przykłady fotografii forensycznej ze względu na sposoby ich użycia i wykorzystania do identyfikacji konkretnych obiektów. Jest to punkt, w którym kończy się rola historyka jako badacza przeszłości, z możliwością otwarcia pola innym perspektywom badawczym, w tym forensyki rozumianej jako archeologia sądowa. Jednak przykłady użycia archiwalnych obrazów skłaniają do zadania pytania nie o to, czy to one potrzebują aparatu forensyki, aby móc je zbadać, ale czy to nie forensyka właśnie potrzebuje tych fotografii? Czy zlokalizowanie masowych grobów w obozach śmierci i innych miejscach po ludobójstwie byłoby możliwe bez dokumentacji fotograficznej? Historia prowadzonych przez ostatnie lata badań archeologicznych dowodzi, że każdą taką praktykę poprzedza szczegółowa

${ }^{38}$ Pozwalają one bowiem, przez ustalenie miejsca ustawienia aparatu, na identyfikację struktury obozu, ogrodzenia czy innych obiektów. W niektórych przypadkach fotografie pokazują cechy krajobrazu, które mogą wskazywać na miejsce, gdzie znajduje się grób. Możliwe jest także robienie zdjęć współczesnego krajobrazu z tej samej pozycji, jeśli wystarczająco dobrze rozpoznane zostaną cechy fotografii z epoki, co jednocześnie otwiera możliwość porównania różnych warstw miejsca i zmian w krajobrazie. Fotografie, zdaniem Colls, mogą również służyć do identyfikacji fizycznych pozostałości znalezionych nad ziemią (np. fragmentów budynków, obozowej infrastruktury), dzięki czemu łatwiejsze staje się poznanie ich pierwotnego kształtu i funkcji, jaką dane obiekty pełniły. Możliwe jest także stworzenie cyfrowej rekonstrukcji obiektów przez fotografie, o ile ich usytuowanie i funkcja zostaną potwierdzone innymi metodami badań. Pierwsze powojenne fotografie z Treblinki ułatwiły brytyjskiej archeolożce ustalenie i potwierdzenie sposobów pozbywania się zwłok ofiar w obozach. W tym przypadku analiza relacji pisanych pochodzących od naocznych świadków (Rachela Auerbach) została uzupełniona danymi ikonograficznymi, te z kolei - ustaleniami archeologów. Colls przywołuje w swoim tekście ciekawy przypadek z procesu Eichmanna, na którym dr Hermann zeznaje, że w czasach tużpowojennych pola Treblinki usiane były kośćmi, czaszkami oraz tysiącami par butów. Użycie przez Colls fotografii z zasobów Yad Vashem może być przykładem zastosowania podejścia forensycznego w badaniach miejsc ludobójstwa i przyczynkiem do przeprowadzenia badań w terenie, których założeniem byłoby zlokalizowanie, odnalezienie, a w konsekwencji zabezpieczenie i upamiętnienie miejsc masowego pochówku (Sturdy Colls, Holocaust Archaeologies..., s. 129-131; eadem, O tym, co minęło, lecz nie zostało zapomniane. Badania archeologiczne na terenie byłego obozu zagłady $w$ Treblince, tłum. Ewa Felska, Jerzy Giebułtowski, „Zagłada Żydów. Studia i Materiały” 2012, nr 8, s. 98-99). 
kwerenda archiwalna oparta na materiałach graficznych: planach, mapach, rysunkach, szkicach, wreszcie - fotografii. Dorobek pierwszych śledztw również nie pozostaje w przypadku takich badań bez znaczenia ${ }^{39}$. W dodatku obecne zainteresowanie badaniami archeologicznymi na terenach naznaczonych ludobójstwem jest w jakimś stopniu kontynuacją pierwszych śledztw, wynikającą ze zmiany paradygmatu ${ }^{40}$. Zwrot w myśleniu o obozach, polegający na ponownym traktowaniu ich przede wszystkim jako miejsc zbrodni, pozwolił na otwarcie się ku innowacyjnym metodom eksploracji. Współczesne techniki wizualizacji, takie jak mapowanie czy fotografia lotnicza, pozwalają zlokalizować konkretne obiekty, w tym masowe groby bez ich naruszania. Istnieje jednak, jak zauważa David Shneer, pewien konflikt wynikający z relacji między subiektywnością zapisu fotograficznego a potrzebą zdobywania obiektywnych dowodów. Mimetyczne odtworzenie obrazu na podstawie mapowania jest „nową formą widzenia” tego, co znajduje się pod ziemią, a więc jest niewidoczne gołym okiem. Powstały w wyniku technicznych procesów obraz jest subiektywną interpretacją, a być może także przekształceniem zapisywanego obiektu. Tymczasem, pisze Shneer, praktyka gromadzenia dowodów wymaga obiektywności ${ }^{41}$. Jego zdaniem materiały dowodowe, bez względu na swoją siłę sprawczą i niepodważalną użyteczność w badaniach obozów śmierci, potrzebują kontekstu w postaci relacji świadków. Wybrzmiewa tu zatem troska o pewien rodzaj etycznego konfliktu wynikającego z przesunięcia w stronę metod forensycznych. Chodzi o postępujące wykluczanie zeznań świadków, traktowanych jako niewiarygodne, na rzecz dowodów rzeczowych i śladów, których analiza dostarcza - uważanych za niepodważalne - wyników. Eyal Weizman pisał, że zwrot forensyczny jest dowodem na to, iż od ery świadka współczesna refleksja weszła w erę dowodu ${ }^{42}$. Podobne zjawisko

\footnotetext{
${ }^{39}$ Wagę materiałów źródłowych podkreślają autorzy pracy na temat wykopalisk archeologicznych na terenie byłego obozu w Sobiborze. Czytamy: „Istotnym uzupełnieniem opracowywanych planów przygotowujących kolejne ekspedycje archeologiczne do prac w terenie były materiały historiograficzne. Ich analiza i weryfikacja pod kątem praktycznej archeologicznej przydatności była bardzo ważnym aspektem korygującym ostateczny kształt metodologii i zakres prac geofizycznych oraz wykopaliskowych. Ważną rolę w tym względzie odegrały te wszystkie źródła historyczne, które mogły pomóc w opisaniu tego, co po całkowicie zlikwidowanym i zniszczonym obozie mogło jeszcze pozostać w ziemi w postaci zachowanych reliktów, oraz [...] tego, co w wyniku dotychczas prowadzonych dochodzeń, śledztw i badań naukowych udało się ustalić na temat topografii byłego obozu (szczególną uwagę zwracano na źródła o charakterze graficznym: mapy, szkice, rysunki i zdjęcia...)”. Analiza zdjęć lotniczych Luftwaffe pozwoliła też ustalić, że obszar obozu był większy, niż zakładały plany sytuacyjne komisji z 1945 r. (Sobibór. Archeologia terenu po byłym nazistowskim obozie zagłady 2000-2017, red. Marek Bem, Warszawa-Włodawa: Fundacja Polsko-Niemieckie Pojednanie, 2019, s. 39-41).

${ }^{40}$ Shneer, Is Seeing Believing?..., s.77.

${ }^{41}$ Ibidem, s. 79.

${ }^{42}$ Thomas Keenan, Eyal Weizman, Mengele's Skull. The Advent of a Forensic Aesthetics, Berlin: Sternberg Press/Portikus, 2012, s. 12-13.
} 
zauważa Ewa Domańska, wskazując, że dowody rzeczowe wypierają ludzkich świadków, ponieważ jako przedmiot analiz laboratoryjnych dostarczają niezawodnych, twardych danych w przeciwieństwie do ludzkiej pamięci, która jest nieweryfikowalna ${ }^{43}$.

\section{Trop trzeci: estetyka forensyczna, przeciw estetyka i wrażliwość forensyczna}

Trzeci trop, na jakim oprzeć można próbę scharakteryzowania fotografii forensycznej, tkwi w strategii krytycznego odczytania i wykorzystania metod sądowych wobec dominujących narracji. W literaturze podejmującej zagadnienie forensyki jako kontrmetody interpretacji obrazów mówi się o estetyce forensycznej (forensic aesthetics), przeciwestetyce (counter-forensics) lub wrażliwości forensycznej ${ }^{44}$. Trzeba jednak zaznaczyć, że pojęcie estetyki forensycznej ma swoje źródła w standardowych metodach kryminalistycznych i dotyczy sposobów wizualnej reprezentacji argumentów, wyników dochodzenia lub badań antropologów sądowych w przestrzeni publicznej, na forum: „Forensyka nie dotyczy po prostu nauki, lecz również prezentacji naukowych ustaleń, nauki jako sztuki perswazji. Wywodzona z łacińskiego słowa forensis, ma jednakże swoje korzenie w słowie forum, a zatem także w praktyce i umiejętności toczenia sporu przed zgromadzeniami o charakterze politycznym lub prawnym", piszą Keenan i Weizman ${ }^{45}$. Praktyki estetyczne, takie jak film czy fotografia, zostają wykorzystane do wizualnego zestawienia danych, obrazów i faktów w taki sposób, aby móc „zmontować” spójną i perswazyjną historię. Na poziomie forum wizualny przekaz zostaje wzmocniony retoryką, elementami performansu, dramatyzacji ${ }^{46}$. Jednocześnie, istotą estetyki forensycznej jest - jak sugerują Keenan i Weizman - nadanie głosu obiektom, ożywienie ich za pomocą naukowej narracji. Najbardziej spektakularnym przykładem sukcesu estetyki forensycznej były badania nad identyfikacją szczątków Josefa Mengelego ${ }^{47}$.

${ }^{43}$ Domańska, Nekros..., s. 137.

${ }^{44} \mathrm{O}$ wrażliwości forensycznej zob.: Jacob Lund, Acts of Remembering in the Work of Esther Shalev-Gerz - From Embodied to Mediated Memory [w:] Revisiting Holocaust. Representation in the Post-Witness Era, red. Tanja Schult, Diana I. Popescu, New York: Palgrave Macmillan, 2015, s. 28-34.

${ }^{45}$ Keenan, Weizman, Mengele's Skull..., s. 28.

${ }^{46}$ Forensic Aesthetics, https://www.ica.art/forensic-aesthetics (dostęp 28 II 2020 r.).

${ }^{47}$ Historia identyfikacji szczątków niemieckiego zbrodniarza pokazuje, jak kluczowe dla wyników śledztwa i badań antropologów sądowych mogą być metody wizualizacji polegające na wykorzystaniu obrazu fotograficznego. Porównanie fotografii czaszki ze znaną fotografią Mengelego z SS metodą nałożenia na siebie dwóch obrazów okazało się przełomowe dla całego przedsięwzięcia. Dzięki metodom wizualnej reprezentacji naukowych argumentów udało się naukowcom przekonać sędziów, prawników, opinie publiczną, wreszcie - samych świadków Holokaustu. Poza tym przypadek czaszki Mengelego wprowadził do nauki i antropologii obrazu nową metodologię, którą wyznacza skonstruowanie perswazyjnej, wizualnej reprezentacji: z dwóch fotografii - archiwalnej i współczesnej - powstaje zupełnie nowy obraz. 
Potencjalność estetyki forensycznej jest wpisana w relacje władzy. Możliwość kontekstualizacji dowodów, w tym fotografii i uwikłania ich w różne sytuacje dyskursywne, stanowi wyzwanie, przed jakim staje refleksja humanistyczna. Stąd być może w studiach nad kulturą wizualną pojawiła się nowa tendencja, która w estetyce forensycznej widzi pewną strategię politycznej kontestacji. Jako pierwszy zwrócił na to uwagę krytyk fotografii Allan Sekula, formułując pojęcie przeciwforensyki. W eseju pt. Photography and the Limits of National Identity pisał, że aparat forensyczny ukonstytuowany jako narzędzie politycznej opresji może być także polem oddziaływania strategii oporu. Posługując się prostą sekwencją słów: identyfikacja - anihilacja - identyfikacja, Sekula pokazuje działanie schematu, który zaczyna się od praktyk państwowego kreowania, ujarzmiania i wizualnego tworzenia obcego, a kończy na fizycznym ujarzmieniu w postaci ludobójczych akcji. Ponowna identyfikacja jest tutaj natomiast aktem sprzeciwu, polegającym na rozpoznaniu szczątków ludzkich jako śladów ofiar represyjnych reżimów łamiących prawa człowieka. Fotografia w pierwszym przypadku, zauważa Sekula, funkcjonuje jako narzędzie opresji, za pomocą którego możliwe jest wykreowanie stereotypowego wizerunku wroga. Zasadą identyfikacji kontestującej będzie poszukiwanie, zbieranie i tworzenie nowych archiwów, których dostarczyć mają narzędzia archeologii i medycyny sądowej, skupionych na poszukiwaniu i rozpoznawaniu ludzkich szczątków ${ }^{48}$. W tym znaczeniu zwrot forensyczny staje po stronie ofiar i praw człowieka.

Z zaangażowanego podejścia Sekuli wynika kilka istotnych wniosków, o czym pisze Thomas Keenan. Każda zbrodnia ludobójstwa pozostawia po sobie ślady, które są wyzwaniem dla forensyki. Przeciwforensyka, ekshumacja i identyfikacja ciał ofiar represji, staje się kluczem do procesu politycznego oporu i żałoby. Forensyka jako „ponura nauka” może być fundamentem humanizmu określanego mianem „humanizmu żałobnej reindywidualizacji” (mournful re-individuation) i kolektywnej pamięci o cierpieniu. Galerie kości i innych śladów są niezbędne, aby sprzeciwić się ludobójczym praktykom, których celem było i jest nie tylko zniszczenie człowieka, lecz także jego historii i prawa do życia ${ }^{49}$. W ramach omawianego wyżej podejścia teoretycznego fotografia forensyczna działa tak jak dowód w dochodzeniu kryminalnym, jednak w innym wymiarze jest jednocześnie świadectwem, ale usankcjonowanym prawnie, co oznacza, że trudno ją podważyć ${ }^{50}$.

0 estetyce forensycznej jako alternatywie dla dotychczasowych reprezentacji wojny i ludobójstwa pisze także Paul Lowe. Fotografie pokazujące topografie

Za jego skomponowanie odpowiedzialny był niemiecki fotograf i patolog, Richard Helmer (Keenan, Weizman, Mengele's Skull..., s. 30-35).

${ }^{48}$ Allan Sekula, Photography and the Limits of of National Identity, „,Grey Room” 2014, nr 55, http://www.greyroom.org/issues/55/12/photography-and-the-limits-of-national-identity/ (dostęp 28 II 2020 r.).

${ }^{49}$ Thomas Keenan, Counter-Forensics and Photography, „Grey Room” 2014, nr 55, s. 70-71.

${ }^{50}$ Ibidem, s. 73. 
miejsc masowych zbrodni są dzisiaj jedną z najważniejszych form ich wizualnego dokumentowania. Polegają one na "estetyce dystansu” i obserwacji, wywołujących u odbiorcy „inny sposób patrzenia” i - jako skupione na rzeczowych śladach zbrodni i konfliktów - zachęcają do swobodnej kontemplacji skoncentrowanej na detalach. Lowe nazywa to „procesem czynnego prześwietlenia fotografii", przez dialog z obrazem i zaangażowanie patrzącego w trybie badawczym (investigative mode) ${ }^{51}$. Jako studium przypadku autor wybiera współczesne reportaże, których twórcy nie przedstawiają bezpośrednio ludzkiego cierpienia. Stoi ono bowiem niejako za artefaktami, przestrzeniami i miejscami naznaczonymi ludzką obecnością, która w momencie tworzenia reportażu ma już jedynie widmowy charakter, nadając miejscom i rzeczom ładunek afektywny.

Nowe, inspirowane teorią Sekuli czy Lowego spojrzenie na fotografię forensyczną ma kilka podstawowych właściwości. Pierwszą jest odejście od przedstawień ludzkich świadków i ich cierpienia, przesunięcie granic polegające na włączeniu w obszar wspólnoty świadków nie-ludzkich i postludzkich sprawców (non-human and post-human agents), którzy są nie tylko metonimicznym odniesieniem do ludzkiej krzywdy, ale samodzielnymi bytami posiadającymi swoją historię i potencjalność. Po drugie: ważne jest nowe spojrzenie na fotografie i umiejętność innego czytania, niejako przeciwko wypracowanym wizualnym nawykom. Lowe twierdzi zatem, że musimy od nowa nauczyć się patrzeć tak, żeby widzieć, sugerując "głębokie odczytanie”. Wreszcie, estetyka forensyczna nie będzie już dłużej posługiwała się estetyzacją cierpienia i ponowną wiktymizacją ofiar ${ }^{52}$.

Zdjęcia z obozów śmierci powinny angażować patrzącego do partycypacji w nowych praktykach wizualnych wobec fotografii Holokaustu. Ikoniczne przedstawienia, które znane są m.in. dzięki powtórzeniom, znieczuliły nasze spojrzenie i oswoiły z ich tragicznym przekazem. Wyłonienie się innych obrazów, być może, stworzy nową przestrzeń i „nową ikonografię Zagłady”, jakże odległą od uniwersalizacji pojedynczych obrazów cierpienia (przykład chłopca z warszawskiego getta) ${ }^{53}$ i tego, co Lowe nazywa „znudzeniem współczuciem” (compassion fatigue) ${ }^{54}$. W takim rozumieniu estetyka forensyczna jest praktyką włączania w obręb ikonografii nowych obrazów, kontrstrategią, która fetysz dowodu zastępuje estetyką troski i tym, co Roma Sendyka nazywa upomnieniem się o nieżywych i „humanistyką forensycznej wrażliwości” ${ }^{55}$. Dodałabym, że w grę wchodzi tutaj także troska o ludzi, jak i nie-ludzkie byty oraz przyszłość gatunków.

${ }^{51}$ Paul Lowe, Traces of Traces. Space, Objects and the Forensic Turn, „Humanities” 2018, nr 7, s. 6.

${ }^{52}$ Ibidem, s. 3.

${ }^{53}$ Por. Fédéric Rousseau, Żydowskie dziecko z Warszawy, tłum. Tomasz Swoboda, Gdańsk: słowo/obraz terytoria, 2012.

${ }^{54}$ Lowe, Traces of Traces...

${ }^{55}$ Roma Sendyka, W imię zmarłych: humanistyka forensycznej wrażliwości i publicznej prawdomówności, „Teksty Drugie” 2017, nr 1, s. 81-90. 


\section{Uwagi końcowe}

Zasadniczym pytaniem pojawiającym się w rozważaniach nad zaproponowanym materiałem badawczym jest pytanie o funkcję, jakie współcześnie fotografie mogą spełniać w refleksji humanistycznej, a zwłaszcza w badaniach historycznych. Pierwsze skojarzenie kieruje naszą uwagę ku powojennej historii obozów zagłady, ich destrukcji i zaniechań, jeśli chodzi o politykę (nie)upamiętnienia. Przez długie lata tereny po obozach śmierci w Treblince, Bełżcu, Chełmnie czy Sobiborze pozostawały zapomniane i zaniedbane, nie wpisywały się - jak Oświęcim czy Majdanek - w oficjalną politykę historyczną komunistycznego rządu. Zofia Wóycicka zwraca przy tym uwagę, że były one systematycznie rozgrabiane przez poszukiwaczy złota i kosztowności ${ }^{56}$. Na brak zainteresowania tymi miejscami wpłynęło kilka ważnych czynników, między innymi to, że obozy te zostały przez Niemców zrównane z ziemią po likwidacji, a więc właściwie nie zachowały się na ich terenach żadne widoczne relikty (budynki, baraki, krematoria). Garstka ocalałych nie miała też takiego wpływu na politykę pamięci, jak byli więźniowie obozów koncentracyjnych skupieni w organizacjach takich jak ZBoWiD czy PZbWP. Nie było więc nikogo, kto chciałby te tereny upamiętnić. Znaczenie miał również fakt, że były to miejsca żydowskiej martyrologii, a więc nie można było wpisać ich w oficjalny, poloncentryczny dyskurs. Jedynymi organizacjami, jakie wykazywały zainteresowanie tymi terenami, były Centralny Komitet Żydów Polskich oraz Centralna Żydowska Komisja Historyczna ${ }^{57}$.

Fotografie z Bełżca i Treblinki mogą być interesującym źródłem historycznym do badań nad powojenną historią obozów śmierci, nad stopniem ich dewastacji, stosunku polskiej ludności do żydowskich miejsc pamięci. Oglądanie tych zdjęć przypomina ponownie o debacie, jaka toczy się od czasu głośnych prac Jana Tomasza Grossa. Jedno ze zdjęć z książki Złote żniwa - być może wykonane w podobnym czasie i przedstawiające prawdopodobnie grupę kopaczy na polach Treblinki - stało się punktem wyjścia antropologicznego opisu i próby rozstrzygnięcia skomplikowanego tematu obrzeży Zagłady ${ }^{58}$. Ten przykład pokazuje jednak także, jak trudnym i niepewnym źródłem jest fotografia, jeśli nie dostarcza wiarygodnych informacji. Poznanie historyczne będzie zatem zmierzać do ścisłej relacji obrazu z innymi źródłami, ponieważ nie ma innej

${ }^{56}$ Zofia Wóycicka, Przerwana żałoba. Polskie spory wokół pamięci nazistowskich obozów koncentracyjnych i zagłady 1944-1950, Warszawa: Trio, 2009, s. 270.

${ }^{57}$ Ibidem, s. 270-271. Por. także źródła: Archiwum Żydowskiego Instytutu Historycznego (dalej AŻIH), 209/38, Sprawozdanie z dotychczasowych wyników dochodzenia w sprawie obozu śmierci dla Żydów w Treblince; AŻIH, 209/41, Odpis Sprawozdania Głównej Komisji dla Zbadania Zbrodni Hitlerowskiej w Polsce o Treblince z 1945 r. - „Do Centralnego Komitetu Żydów Polskich w Warszawie” z pobytu komisji na polach byłego obozu Treblinka.

${ }^{58}$ Jan Tomasz Gross, współpraca Irena Grudzińska-Gross, Złote żniwa. Rzecz o tym, co się działo na obrzeżach Zagłady, Kraków: Znak, 2011. 
możliwości, biorąc pod uwagę aparat metodologiczny historyka, jak dążenie do syntetycznego ujęcia tematu.

Czerpiąc z propozycji zwrotu forensycznego i/lub estetyki forensycznej uwaga badacza będzie natomiast skupiała się nie tylko na gromadzeniu faktów i informacji, lecz także na możliwościach interpretacyjnych podsuwanych przez podejścia teoretyczne. Będzie to więc głównie zwrócenie się ku pierwotnym praktykom zbierania dowodów zbrodni osadzonych w konkretnej rzeczywistości polityczno-społecznej oraz przyjęcie perspektywy materialnych świadków (rzeczy, szczątków ludzkich, krajobrazu/natury) jako sprawców (agents) w „sytuacji testymonialnej” (Roma Sendyka), którą określa zwrot w stronę materialności i stopniowe porzucenie optyki (ludzkiego) świadka ${ }^{59}$. Jak podaje Susan Schuppli, artystka i badaczka praktyk forensycznych, współczesne dochodzenia sądowe i kryminalne opierają się na swoistym „przesunięciu punktu ciężkości ku zorientowanej na przedmioty kulturze jurydycznej, której domeną są materia i kody"60. Uwaga ta dotyczy zarówno materialności fotografii (faktury, uszkodzeń, przetwarzania obrazu przez jego kopie, odbitki itp.), jak również jej zdolności przetwarzania rzeczy w obraz (poprzez uchwycenie materialnych resztek, dowodów, świadków) ${ }^{61}$.

Forensyka, stawiając na samodzielność i odrębność nie-ludzkich świadków, wprowadza zatarg między zorientowaną antropocentrycznie i narracyjnie (w sensie skupienia na źródłach pisanych) tradycyjną historiografią a możliwościami emancypacyjnymi i kontrstrategiami, które stawiają opór usankcjonowanym dyskursom historii. Wraz z obrazem fotograficznym, który nie epatuje „widokiem cudzego cierpienia” (Sontag) i jego figurami manifestującymi się w postaci więźnia, kobiety, żydowskiego dziecka, a jedynie indeksem widmowej obecności człowieka, może wpisywać się w zasugerowany przez Didi-Hubermana paradygmat „obrazu-rozdarcia”, który wyłania się w miejscu brakującego świadectwa, niezapisanej i niewyartykułowanej luki, negując tym samym przekonanie o niewyrażalności Zagłady i niewypowiedzianym Auschwitz ${ }^{62}$. To także moment zwrócenia się ku archiwom fotografii, często dotychczas nieodkrytym, usytuowanym w określonych, płynnych porządkach dyskursywnych (od obrazu-dowodu do obrazu-archiwum). W miarę ich odkrywania (przykład zbioru odnalezionych niedawno fotografii z Sobiboru) przekonujemy się coraz bardziej, że Holokaust nie jest - jak chciałby Claude Lanzmann - „wydarzeniem bez obrazów", ale że jest wyobrażany głównie poprzez obrazy, które przełamują

${ }^{59}$ Sendyka, Stać na miejscu śmierci..., s. 97.

${ }^{60}$ Susan Schuppli, Przedstawianie dowodów: taśma [w:] Rzeczowy świadek..., s. 78.

${ }^{61}$ Ibidem, s. 77. 0 uszkodzonych fotografiach z Zagłady por. Jacek Leociak, Okaleczone obrazy. Uszkodzone fotografie (z) Zagłady jako wyzwanie interpretacyjne [w:] Zagłada. Współczesne problemy rozumienia i przedstawiania, red. Ewa Domańska, Przemysław Czapliński, Poznań: Wydawnictwo PSP, 2009.

${ }^{62}$ Didi-Huberman, Obrazy mimo wszystko... 
„estetykę rewiktymizacji”63. Estetyka forensyczna zaś może być użytecznym narzędziem oporu, które wskaże sposoby uwikłania wizualności w relacje władzy i wiedzy oraz metody niejako odzyskiwania obrazu przez praktyki krytycznego odczytania i analizy ${ }^{64}$.

Fotografie z obozów śmierci przypominają o tym, co zapomniane, nieupamiętnione, odrzucone; przywracają pewną historię, która potrzebowała konkretnego (sądowego, prawnego, dowodowego) aparatu, aby mogła zostać opowiedziana, a sprawcy osądzeni. Dyskurs jurydyczny pozostaje jednak hermetyczny, nie inicjuje pracy pamięci, jest narzędziem ustanawiania nowego porządku politycznego i społecznego. Moc udowadniania i poświadczania ma wymiar techniczny, uporządkowany - powiedzielibyśmy - „obramowany” (Butler). Zmiana znaczeń, włączenie ich w praktyki kommemoratywne wymaga ingerencji z zewnątrz, zbudowania opowieści. Dowód-świadectwo, jak sugeruje Mikołaj Smykowski, musi wyjść poza to, co wypowiedziane, a perspektywa forensyczna jest poszukiwaniem innych niż językowe form reprezentacji Holokaustu ${ }^{65}$.

\section{BIBLIOGRAFIA}

\section{Źródła archiwalne}

Archiwum Żydowskiego Instytutu Historycznego (AŻIH)

209/38, „Extermination Camp at Treblinka”, Sprawozdanie z dotychczasowych wyników dochodzenia w sprawie obozu śmierci dla Żydów w Treblince

209/41, Odpis Sprawozdania Głównej Komisji dla Zbadania Zbrodni Hitlerowskiej w Polsce o Treblince z 1945 r. - „Do Centralnego Komitetu Żydów Polskich w Warszawie" z pobytu komisji na polach byłego obozu Treblinka

\section{Źródła publikowane}

Archiwum Ringelbluma. Konspiracyjne Archiwum Getta Warszawy, t. 13: Ostatnim etapem przesiedlenia jest śmierć. Pomiechówek, Chełmno nad Nerem, Treblinka, oprac. Ewa Wiatr, Barbara Engelking, Alina Skibińska, Warszawa: WUW i ŻIH, 2013.

Komunikat Polsko-Radzieckiej Komisji Nadzwyczajnej do zbadania zbrodni niemieckich dokonanych w obozie unicestwienia na Majdanku w Lublinie, Moskwa, 1944.

Prawda o Majdanku, Lublin: PKWN, 1944.

Protokół oględzin obozu śmierci w Bełżcu, Nr R. 102/46, Nr Ds. 1604/45. Zamość [w:] Obóz zagłady $w$ Bełżcu $w$ relacjach ocalonych i zeznaniach polskich świadków, red. Dariusz Libionka, Lublin: Państwowe Muzeum na Majdanku, 2013.

Protokół przesłuchania świadka z dnia 18 października 1945 r., Nr R. 102/46, Nr akt. Kps.302/45 [w:] Obóz zagłady w Bełżcu w relacjach ocalonych i zeznaniach polskich świadków, red. Dariusz Libionka, Lublin: Państwowe Muzeum na Majdanku, 2013.

${ }^{63} \mathrm{O}$ zasadności publikowania fotografii Zagłady por. Susan A. Crane, Choosing Not to Look. Representation, Repatriation and Holocaust Atrocity Photography, „History and Theory” 2008, nr 3, s. 309-330.

${ }^{64}$ Por. Gillian Rose, Interpretacja materiałów wizualnych, tłum. Ewa Klekot, Warszawa: PWN, 2010.

${ }^{65}$ Mikołaj Smykowski, Krajobraz pośmiertny. Las Rzuchowski w perspektywie forensycznej, „Konteksty. Polska Sztuka Ludowa” 2018, nr 4, s. 355-368. 
Sprawozdanie z wyników dochodzenia w spr. obozu śmierci w Bełżcu, Nr R. 102/46, Nr 1. Dz. 1604/45 [w:] Obóz zagłady w Bełżcu w relacjach ocalonych i zeznaniach polskich świadków, red. Dariusz Libionka, Lublin: Państwowe Muzeum na Majdanku, 2013.

\section{Fotografie \\ Żydowski Instytut Historyczny}

neg. Bełż 042, neg. GKBZPNP 67805

neg. Bełż 034, neg. GKBZPNP 58726

neg. 037

TRE 002, TRE 005, TRE 007, TRE 017, TRE 018, TRE 019, TRE 023

1772, 1755

\section{Literatura przedmiotu}

Auerbach Rachela, Treblinka. Reportaż, tłum. Karolina Szymaniak, „Zagłada Żydów. Studia i Materiały" 2012, nr 8.

Crane Susan A., Choosing Not to Look. Representation, Repatriation and Holocaust Atrocity Photography, „History and Theory” 2008, nr 3.

Didi-Huberman Georges, Obrazy mimo wszystko, tłum. Mai Kubiak Ho-Chi, Kraków: Universitas, 2008.

Domańska Ewa, Nekros. Wprowadzenie do ontologii martwego ciała, Warszawa: Wydawnictwo Naukowe PWN, 2017, s. 137.

Fresco Nadine, Śmierć Żydów. Fotografie, tłum. Magdalena Kamińska-Maurugeon, Wołowiec: Czarne, 2011.

Gross Jan Tomasz, wspólpraca Irena Grudzińska-Gross, Złote żniwa. Rzecz o tym, co się działo na obrzeżach Zagłady, Kraków: Znak, 2011.

Human Remains and Identification. Mass Violence, Genocide and „Forensic Turn”, red. Élisabeth Anstett, Jean-Marc Dreyfus, Manchester: Manchester University Press, 2017.

Keenan Thomas, Counter-forensics and Photography, „Grey Room” 2014, nr 55.

Keenan Thomas, Weizman Eyal, Mengele's Skull. The Advent of a Forensic Aesthetics, Berlin: Sternberg Press/Portikus, 2012.

Leociak Jacek, Okaleczone obrazy. Uszkodzone fotografie (z) Zagłady jako wyzwanie interpretacyjne [w:] Zagłada. Współczesne problemy rozumienia i przedstawiania, red. Ewa Domańska, Przemysław Czapliński, Poznań: Wydawnictwo PSP, 2009.

Lowe Paul, Traces of Traces. Space, Objects and the Forensic Turn, „Humanities” 2018, nr 7.

Lund Jacob, Acts of Remembering in the Work of Esther Shalev-Gerz - From Embodied to Mediated Memory [w:] Revisiting Holocaust. Representation in the Post-Witness Era, red. Tanja Schult, Diana I. Popescu, New York: Palgrave Macmillan, 2015.

Mapping the Forensic Turn. Engagements with Materialities of Mass Death in Holocaust Studies and Beyond, red. Zuzanna Dziuban, Wien: New Academic Press, 2017.

Obóz zagłady w Bełżcu $w$ relacjach ocalonych i zeznaniach polskich świadków, red. Dariusz Libionka, Lublin: Państwowe Muzeum na Majdanku, 2013.

Rose Gillian, Interpretacja materiałów wizualnych, tłum. Ewa Klekot, Warszawa: PWN, 2010.

Rouillé André, Fotografia. Między dokumentem a sztuka współczesnq, tłum. Oskar Hedemann, Kraków: Uniwersitas, 2007.

Rousseau Fédéric, Żydowskie dziecko z Warszawy, tłum. Tomasz Swoboda, Gdańsk: słowo/obraz terytoria, 2012.

Rusiniak Martyna, Obóz zagłady Treblinka II w pamięci społecznej (1943-1989), Warszawa: Wydawnictwo Noriton, 2008. 
Rusiniak-Karwat Martyna, Okres profanacji i zapomnienia. Treblinka II [w:] Co wiemy o Treblince? Stan badań, red. Edward Kopówka, Siedlce: Muzeum Regionalne, 2013.

Schuppli Susan, Przedstawianie dowodów: taśma [w:] Rzeczowy świadek, red. Katarzyna Grzybowska, Sylwia Papier, Roma Sendyka, Kraków: Wydawnictwo UJ, 2019.

Sendyka Roma, W imię zmarłych: humanistyka forensycznej wrażliwości i publicznej prawdomówności, „Teksty Drugie” 2017, nr 1.

Sendyka Roma, Stać na miejscu śmierci [w:] Rzeczowy świadek, red. Katarzyna Grzybowska, Sylwia Papier, Roma Sendyka, Kraków: Wydawnictwo UJ, 2019.

Sendyka Roma, Karina Jarzyńska, Mytych Jagoda i in., Nie-miejsca pamięci. Elementarz, Kraków: Ośrodek Badań nad Kulturami Pamięci, 2017.

Shneer David, Ghostly Landscapes. Soviet Liberators Photograph the Holocaust, „Humanity: An International Journal of Human Rights, Humanitarianism and Development" 2014, t. 5.

Shneer David, Is Seeing Believing? Photographs, Eyewitness Testimony, and Evidence of the Holocaust [w:] The Holocaust. Memories and History, red. Victoria Khiterer, Ryan Barrick, David Misal, Newcastle upon Tyne: Cambridge Scholar Publishing, 2014.

Smykowski Mikołaj, Krajobraz pośmiertny. Las Rzuchowski w perspektywie forensycznej, „Konteksty. Polska Sztuka Ludowa” 2018, nr 4.

Sobibór. Archeologia terenu po byłym nazistowskim obozie zagłady 2000-2017, red. Marek Bem, Warszawa-Włodawa, Fundacja Polsko-Niemieckie Pojednanie, 2019.

Struk Janina, Holokaust w fotografiach. Interpretacje dowodów, tłum. Maciej Antosiewicz, Warszawa: Prószyński i S-ka, 2007.

Struk Janina, Images of Women in Holocaust Photography, „Feminist Review” 2008, nr 88.

Sturdy Colls Caroline, Badania archeologiczne w Obozie Zagłady i Karnym Obozie Pracy $w$ Treblince [w:] Treblinka. Historia i pamięć, red. Edward Kopówka, Siedlce: Muzeum Regionalne, 2015.

Sturdy Colls Caroline, Holocaust Archaeologies. Approaches and Future Directions, London: Oxford University Press, 2015.

Sturdy Colls Caroline, 0 tym, co minęło, lecz nie zostało zapomniane. Badania archeologiczne na terenie byłego obozu zagłady $w$ Treblince, tłum. Ewa Felska, Jerzy Giebułtowski, „Zagłada Żydów. Studia i Materiały” 2012, nr 8.

Wóycicka Zofia, Przerwana żałoba. Polskie spory wokół pamięci nazistowskich obozów koncentracyjnych i zagłady 1944-1950, Warszawa: Trio 2009.

Ubertowska Aleksandra, Rachela Auerbach opłakuje ślady, resztki, widma, wyrwy z ziemi, „Teksty Drugie” 2014, nr 1.

Zelizer Barbie, Remembering to Forget. Holocaust Memory Through the Camera's Eye, Chicago-London: University of Chicago Press, 1998.

\section{Netografia}

O'Neil Robin, Tregenza Michael, Belzec Archaeological Investigations. Acknowlegment to the Torun Team of archaeologists and the cartographer, Billy Rutherford, www.holocaustresearchproject.org

Sekula Allan, Photography and the Limits of of National Identity, „Grey Room” 2014, nr 5, http://www.greyroom.org/issues/55/12/photography-and-the-limits-of-national-identity/

Forensic Aesthetics, https://www.ica.art/forensic-aesthetics 